\title{
IMPROVISATION AS STRATEGY: Building an Information Technology Capability
}

\author{
Thi Lien Pham \\ Ernest Jordan \\ Macquarie University \\ Sydney, Australia
}

\begin{abstract}
There is substantial literature on the use of information technology for competitive advantage and organizational transformation. In the main, this literature speaks to the world of IT-capable organizations, pursuing ever more challenging goals. This paper reports on a case study of an organization that had similar aims for its use of IT, but lacked the capability. Senior management chose a strategy of improvisation with the goal of learning-by-doing so that the capability would be developed. The paper assesses the achievements to date, suggests forward paths, and offers guidelines to organizations that find themselves in a similar state.
\end{abstract}

Keywords Competitive advantage, business strategy, IT capability

\section{INTRODUCTION}

The early propositions of competitive advantage through information technology espoused by, among others, McFarlan (1984) and Porter and Millar (1985) later became concerned with the sustainability of that advantage (for example, Clemons and Row 1991; Feeny and Ives 1990). However, for the majority of organizations, this cannot be the case; they cannot all be leaders. The analysis provided by the resource-based view of IT suggests that many organizations must be satisfied with a position of competitive parity where information technologies are viewed as homogeneously distributed (Mata et al. 1995). This matches the position of Carr (2003), where IT is viewed as a utility that cannot deliver any sustainable advantage. However Mata et al. (1995) show that it is the management of IT, rather than the IT itself, that is able to deliver sustainable advantage. They suggest that strongly developed IT management capabilities are able

Please use the following format when citing this chapter:

Pham, Thi Lien, Jordan, Ernest, 2006, in International Federation for Information Processing (IFIP), Volume 206, The Transfer and Diffusion of Information Technology for Organizational Resilience, eds. B. Donnellan, Larsen T., Levine L., DeGross J. (Boston: Springer), pp. 139-156. 
to deliver new applications that have value to the business more often, more reliably, and more effectively.

The IT-led transformation literature also addresses organizations that are IT-capable (Applegate 1994; Bjørn-Andersen and Turner 1994; Turban et al. 2004). The business process reengineering movement (Hammer and Champy 1993) lauded IT as an enabler of the radical changes in the organization. The widely quoted case studies of organizational transformation through IT have a sometimes unwritten assumption that merely choosing the correct IT, making a decision, will enable it to be implemented and the benefits achieved. This may be true for IT-capable organizations (although the stories of project failure are often ascribed to organizations that one would imagine to be generally competent) but for organizations where IT capability is underdeveloped, the achievability of project goals will be seriously in doubt.

What options then are available to the organization that is not IT capable? If a hypothetical SWOT analysis done by the board and senior management shows that, for their organization, IT is a weakness, what can be done? This is especially challenging if the board and senior management are aware that IT is an increasing basis of competition, efficiency, and product development. This paper reports on just such an example, where the senior management needed to transform the IT capability so that IT could transform the organization. Senior management took a decision of improvisation - an attempt at self-sufficiency that could be regarded as a "sink or swim" approach. This is unusual for a conservative, government-owned insurance company anywhere in the world, but perhaps more especially in a developing economy. We report on a farsighted approach that is working and assess its achievements.

\section{THEORETICAL BACKGROUND}

This paper draws on two key literature themes: IT capability and improvisation. These are then combined into a framework for understanding how improvisation may be regarded as a strategy when aiming to build IT capability.

\subsection{IT Capability}

Information technology is generally available to all organizations; there are few purchase restrictions in force around the world. IT is not a scarce resource at its basic commodity level, as Carr (2003) convincingly argued. However, some organizations do better with their IT than others and for some this is a consistent achievement. The key discriminator is not the technology but the management of it (Bharadwaj 2000; Mata et al. 1995). Consistently superior management of IT is an overarching IT capability that enables the organization to deliver real value to the business (Dvorak et al. 1997), and achieve long-term competitiveness (Ross et al. 1996).

But what precisely are these capabilities? Bharadwaj (2000) defined IT capability as the ability to mobilize and deploy IT-based resources in combination with other resources and capabilities. Those IT-based resources are IT infrastructure, human IT resources comprising technical and managerial IT skills, and intangible IT-enabled 
resources such as knowledge assets, customer orientation, and synergy. Ross et al. (1996) argue that competent staff, strong relationships between business and IT, and a reusable technology base are the foundations. However this argument is still short on specifics that would guide an under-achieving organization. Peppard and Ward (2004) mentioned three interrelated attributes of IT capabilities:

- A fusion of business knowledge with IS knowledge

- A flexible and reusable IT platform

- An effective use process (with its two aspects: using the technology and working with information)

Similarly the principles espoused by Dvorak et al. (1997, p. 166), may be goals aimed at in the establishment of organizational capability and can be summarized as

- Business-driven IT

- Business funding of IT

- Flexibility and simplicity

- short term results

- Constant productivity improvements

- Reciprocal understanding between business and IT

but they are not indicators in themselves of achievement or capability. Furthermore, there is little empirical evidence offered to support these propositions.

The approach taken by Feeny and Willcocks (1998) is particularly valuable. Using outsourcing as a test case, or "winnowing" mechanism, they identify the capabilities that an organization must maintain even though its IT is outsourced. They then infer that these same capabilities are precisely those that are needed, and critical, to organizations that do not outsource. Feeny and Willcocks (pp. 357-359) list these core capabilities as

- IS/IT leadership

- Business system thinking

- Relationship building

- Architecture planning

- Making technology work

- Informed buying

- Contract facilitation

- Contract monitoring

- Vendor development

Building on the work of Feeny and Willcocks, Ward and Peppard (2002, pp. 595 $596)$ identified eight key "inabilities" that organizations admitted. These are

- Business strategy: An inability to ensure that business strategy formulation identifies the most advantageous use of information, systems, and technology.

- Benefits delivery: An inability to monitor, measure, and evaluate the benefits delivered from IS/IT investment and use. 
- Managing change: An inability to make the business and organizational changes required to maximize the benefits without detrimental impact on stakeholders.

- Information governance: An inability to define information management policies for the organization and the roles and responsibilities of general management and the IS function.

- Benefits planning: An inability explicitly to identify and plan to realize the benefits from IS investments.

- Business performance improvement: An inability to identify the knowledge and information needed to deliver strategic objectives through improved management processes.

- Information asset management: An inability to establish and operate the processes that ensure data, information, and knowledge-management activities meet organizational needs and satisfy corporate policies.

- Prioritization: An inability to ensure that the portfolio of investments in applications and technology produces the maximum return from the resources available.

This list, when viewed as abilities rather than inabilities forms one of the frameworks for this study. How organizations can make the transition from inabilities to abilities requires other models.

The work of Ciborra is significant but again often speaks of capable organizations. One view he supported for the transition from lower levels of capabilities to higher levels is that of organizational learning. Andreu and Ciborra (1996) develop a model that shows how IT can be used for the development of core capabilities in the organization, although here they are concerned with the role for IT in developing competencies elsewhere in the organization. This model involves three learning loops.

- The routinization loop, which uses resources available in the wider environment to develop work practices.

- The capability loop, which takes these work practices and, through management actions, develops capabilities.

- The strategic loop, which takes capabilities and, when guided by the business mission develops core capabilities in a competitive context (Andreu and Ciborra 1996).

This model is presented in Figure 1. It shows that the development of work practices can occur in isolation from the strategic inputs. In the routine of their work, staff build practices that, when recognized by management, can become the basis of competencies. Tuning these to the needs of the organization's goals and its competitive environment can then build core competencies.

This model can be used to examine the development of IT capability in particular in an organization.

\subsection{Improvisation}

Early work on improvisation drew on concepts from the world of music, jazz in particular, but over time the phenomenon of improvisation within organizations has been 


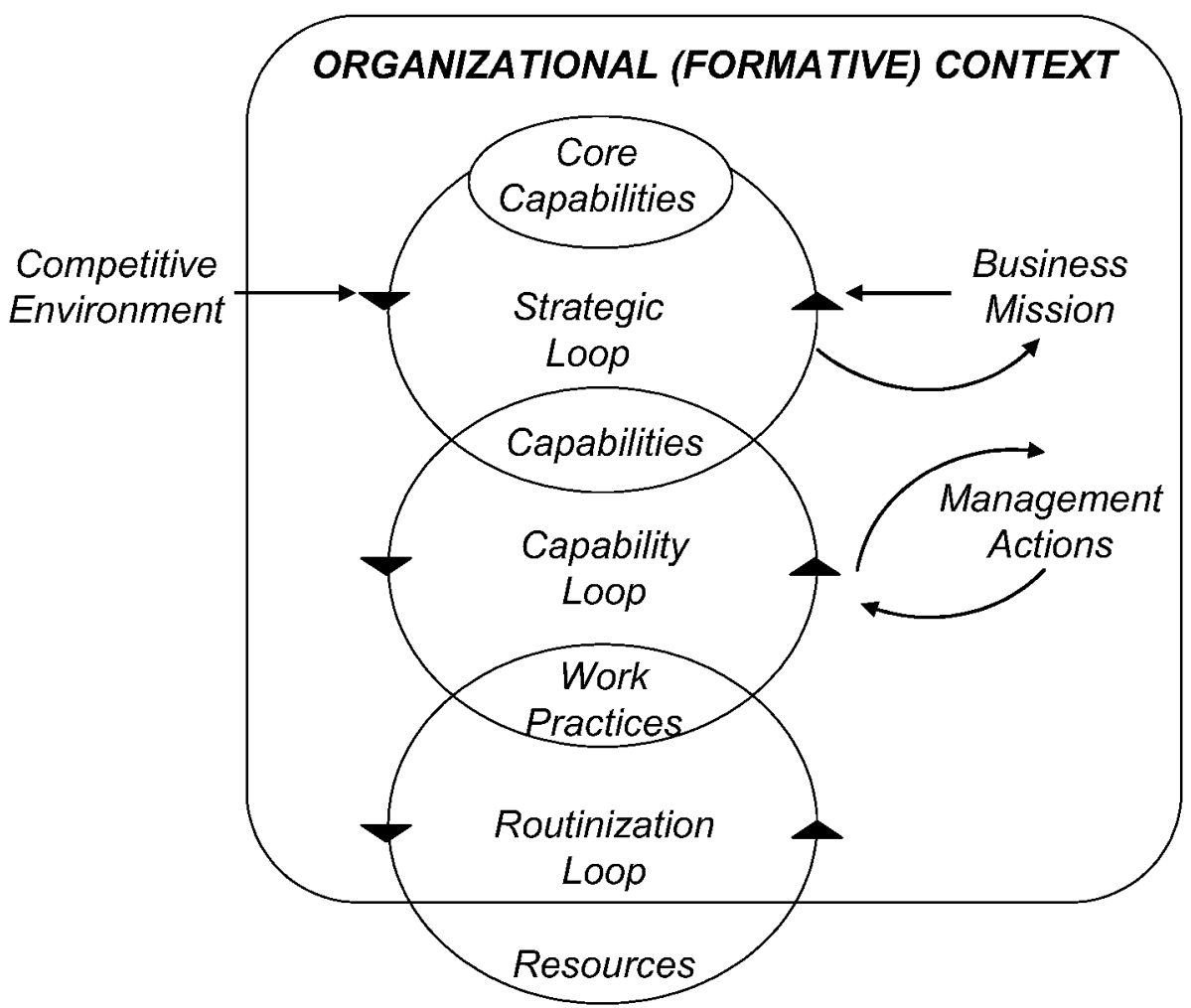

Figure 1. Basic Learning Processes (Reprinted from Journal of Strategic Information Systems (5), R. Andreu and C, Ciborra, "Organizational Learning and Core Capabilities Development: The Role of IT," p. 118, Copyright (C) 1996; used with permission from Elsevier.)

studied in its own right (Barrett 1998; Kamoche 2003). Given that planning and control play such significant roles in management research and practice, one emphasis of the improvisation literature has examined the absence of planning or the restricted time between planning and action (Barrett 1998; Cunha et al. 1999; Moorman and Miner 1998a, 1998b; Weick 1998). A second stream of research deals with spur-of-themoment actions, such as in crisis situations (Weick 1988) or essentially intuitive, spontaneous action without planning (Ciborra 1999).

In bringing concepts of improvisation to the field of information systems, Orlikowski (1996; also Orlikowski and Hoffman 1997) drew reference to the responses to the day-to-day disasters, disruptions, and outages that are unfortunately too common.

Thus we adopt the broad definition of organizational improvisation of Cunha et al. (1999, p. 302) as "the conception of action as it unfolds, by an organization and/or its members, drawing on available material, cognitive, affective and social resources." The specific inclusion of the word available stresses the complementary concept of bricolage, where solutions are developed only from what is available, rather than what 
is best. We further note the point made by Miner et al. (2001) that improvisational action can occur and be studied at any level of analysis, including strategic improvisation by an entire firm.

\subsection{Improvisation Toward IT Capability}

Improvisation could happen at all levels of and in all kinds of organizations (Ciborra 1999; Miner et al. 2001), even in highly structured organizations. Ciborra (1999) reviewed the everyday activity in both emergency and routine circumstances and showed that improvisation is ubiquitous and economically relevant in both market and hierarchy structures. The fifth of the capabilities in the Feeny and Willcocks (1998) model is "rapidly achieving technical progress by one means or another," which expresses one aspect of improvisation. If that technical progress includes a reference to the other capabilities, then we can see that improvisation is compatible with their model. On the other hand, a high-level decision to improvise can be seen as strategic. Silva (2002) shows that improvisation can indeed be a strategic decision. More broadly, the strategic decision may be to improvise rather than a specific, unique improvised decision.

One of the positive outcomes of improvisation is learning, mentioned earlier. Organizations doing improvisation can learn in three ways: learn how to improvise, learn through the formalization/routinization of their improvisation, and learn about themselves and their environment through the action component of improvisation (Cunha et al. 1999). Miner et al. (2001) argued that improvisation can be seen as a special type of short-term, real-time learning itself and that improvisation not only draws on prior learning but may be a factor that influences other, long term organizational learning activities. With the view that "people continually learn and improvise while working" (Brown and Duguid 1991, cited by Ciborra 1999, p. 81), it is believed that the learning that happened in an improvising organization might be both the outcome of improvisation and the "learning in working/learning by doing" process itself. This paper tries to analyze the case of building IT capability in a developing country in relation with this improvisation phenomenon and this view will affect the way that this paper presents and analyzes its case study.

Is improvisation necessarily quick and unexpected, or is it simply the outcomes of improvisation that are unexpected? This sense of improvisation - making do with what you have and making something special out of it-is distinctly different from Silva's (2002) concept, where improvisation is expressed by "quick and unexpected solutions" (p. 129). However, Silva shows that improvisation can indeed be a strategic decision. More broadly, the strategic decision may be to improvise rather than a specific, unique improvised decision.

\section{RESEARCH APPROACH}

The case study presented here concerns the process of building IT capability in a Vietnamese insurance organization, Baoviet. When Baoviet needed a system for its newly created life insurance business, several factors drove it to an improvisation 
approach. However, the main objective was that the business units would learn about IT and the IT unit would learn about business needs, and that this learning would happen on the job. Thus IT capability would be improved. Bao Viet Life became a separate company in 2004.

A case study investigation has been conducted on site at the head office and Hanoi branch of Bao Viet Life. More than 40 managers and IT staff were involved in a study that used interviews and questionnaires. Semi-structured interviews were conducted concerning the evolving capabilities in IT. Simple questionnaires were then used to extend the coverage. The interviews were semi-structured based on the above-mentioned IT capability model and had an average duration of some 2 hours. They were not taped; instead, notes were taken. The risk in this procedure is being not completely faithful to the words used by the interviewees, but it made them feel more comfortable. The questionnaire design also drew on the Ross et al. (1996) study and the Peppard and Ward (2004) capability model. The study received ethics approval from the researchers' university. Besides the interview and questionnaire survey results, many of the company's written documents were collected for the purpose of analysis later.

The case study will be presented; analysis and discussion relating to improvisation theory will follow.

\section{CASE AND ANALYSIS}

Baoviet Insurance Company (Baoviet) has 45 years of experience in providing insurance services. Until 1995, however, this did not include life insurance. By 1995, the gains from economic growth after 10 years of economic reform had substantially improved the living standard of the Vietnamese people. Vietnam experienced a sustainable economic growth rate of about 6 percent during this 10 year period. The demand for life insurance emerged when those with higher incomes started thinking about their longer term living conditions and investments. Baoviet faced the decision of how to develop this potential but avoid the risks and complications of this new form of business.

The life insurance business development project on the table in 1995 included plans of joint-ventures with foreign partners. However, the tender offers were refused and Baoviet decided to develop using its own efforts. Baoviet was then a governmentowned monopoly and did not want to share the potentially strong returns in that initial period and so it decided to develop a local brand of life insurance. The process of developing this new business from scratch was completely by a process of trial and error.

The major challenges for life insurance development were the lack of experience in product development, business procedures, product knowledge of agents and staff, IT development and use, and risk management. However, the life insurance business of Baoviet experienced an unexpectedly strong growth rate and all business functions and systems were under severe pressure. In 2000 Baoviet changed its business strategy for life insurance to "growth and management" with a strong emphasis on improving various aspects of management.

The business model of Baoviet was (and remains) decentralized, with all branches relatively independent in providing services to customers. The head office is responsible for product development, guiding business processes, training, and support. The 
branches are responsible for directly providing products and serving customers. Because of the limitations of the telecommunication infrastructure and low experience in IT development in Vietnam, online data centralization was not feasible at all until recently. That is, branches were required to maintain their own data about policyholders.

It is worth mentioning that a recent entrant (a global player) in the Vietnamese insurance business has significant IT know-how and is using this effectively to build market share.

\subsection{Early Stage}

In 1996, Baoviet launched its life insurance business. This was the first, and monopoly, provider doing life insurance business in the marketplace. In the period from 1996 to 1999 , it was undertaken in only 20 out of the 61 branches. By 2002, all of Baoviet's 61 branches located in all provinces across the country had implemented the life insurance business.

In the early 1990s, there was no substantial Vietnamese software company in the market, let alone one that specialized in insurance. It was not easy to find programmers, and packages were not available in the Vietnamese market. In addition, Baoviet's life insurance business was still small in terms of number of customers and premium income. The first attempt at IT development in 1996 was for management of policies using FoxBase. ${ }^{1}$ This software was developed by a business staff member rather than Baoviet's IT department, which had no knowledge of life insurance. It was first used in two branches in Hanoi and Ho Chi Minh City and then was installed in those branches with life insurance business.

Under the pressure of fast business growth and unforeseen management requirements, the software did not meet business demands and was not stable. It remained outdated even though it was continuously updated. In 1998, a replacement, more comprehensive FoxBase application was launched by the Baoviet IT department. This new system had more functionality and could work with larger volumes of data. However, the IT problems continued mounting. The most common problems were functional errors, inflexible reporting, and little support for decision making, combined with the slow speed of operation. In addition, IT problems were caused by untrained staff. Business staffs were also learning how to establish the new business processes and kept changing their business procedures, especially when launching new products. The IT staff also were exploring business procedures and enhancing their IT skills at the same time. A senior software developer in the current Bao Viet Life IT Centre said,

Baoviet IT staff hadn't got enough knowledge and experience in the life insurance business at that time. So, building in-house software was the right decision. It helped IT staff to learn more technical skills and business knowledge so that they could assess software that external partners offered later.

${ }^{1}$ A competitor product to Ashton-Tate's dBaseIV, then the market leader in PC database software. It had limited multiuser capability and was eventually purchased by Microsoft (now Visual FoxPro). 
By 1999, the information technology market in Vietnam was growing with more IT companies and increasing awareness of IT's role in business. The government especially emphasized its importance as well, giving some encouragement for developing information technology in the country through initiatives such as tax exemptions for importing hardware and software and priority for Internet infrastructure development. The achievements in Vietnam's economic development had improved people's standard of living. The large population (over 80 million) combined with the gradual increase in awareness of life insurance created a large potential life insurance market for Vietnam, which attracted increasing attention from foreign companies. Some were permitted to open for business in Vietnam in 1999, ending Baoviet's monopoly in life insurance. Competition became the emerging issue with which Baoviet's executive management had to prepare to cope. In the 1999 business strategy, it was specified that one of the main principles for developing the information systems was the use of a "selfsufficiency" approach, making use of external resources. They decided that an essential step was outsourcing IT, so they called for presentations from several software application vendors, both local and foreign.

At that time, the life insurance business was still new in Vietnam. Baoviet staff had both insufficient IT skills and insufficient business knowledge. It was particularly challenging for them to assess the sophisticated "total solution" offerings from overseas. These packages seemed to be good but they were thought to be unsuitable to Baoviet's current business situation and organization structure. They would need to be significantly modified to meet the current state of business. If an overseas solution was chosen, Baoviet faced changes to its organizational structure and its business processes that would challenge personnel competence. Changing the organizational structure in a state-owned enterprise would be a difficult task, but changing people was seen to be even harder. It would not only involve major effort but also take time. In addition, the purchase of overseas software would represent a significant budgetary investment to Baoviet.

On the other hand, there were some advantages of choosing local vendors: lower costs; using the Vietnamese language, leading to better and more efficient communication; potential learning while developing software with a partner; and the partner's greater understanding of Vietnamese business culture. The disadvantages were that local vendors had little knowledge of the life insurance business. If they were chosen, Baoviet staff would have to teach them and provide that knowledge. Also they were not as experienced as foreign partners in both their business and technical knowledge.

All things considered, Baoviet's executives decided to go with one local vendor to build its life insurance software using an Oracle environment. With that choice, they could both learn from the partner as well as learn by doing and they could avoid losing a big amount of money and avoid a big mistake if the project failed because of its risks.

\subsection{Local Outsourcing}

Baoviet started its life insurance IT project with the local vendor in 1999 while still using the old software. Baoviet established an IT project group to cooperate with the partner. They had to work intensively to share knowledge of the life insurance business and to specify Baoviet's requirements for the partner. 
In addition to the lack of understanding of the new business and the weakness in project management of Baoviet staff themselves, the Vietnamese partner was similarly inexperienced and lacking in insurance knowledge. After a pause in 2000 to evaluate the project's achievements, it was eventually terminated in 2001 , with an estimated 70 percent completion.

IT staff had gained experience and knowledge from the partner, and in the process they also increased their business knowledge. So, they felt capable of continuing the project in-house. Bao Viet Life's senior management then made the decision to continue building the software in-house. The IT staff had to develop the remaining 30 percent and to modify and correct it to meet business requirements.

\subsection{Insourcing}

In spite of the failure of the project, Baoviet still implemented the partly developed software to all branches across the country. Even though the software was not flexible, could not meet the business demands, and had many errors, it still was much better than the old software. The initial period of in-house development was a very hard time for the IT staff. One IT Manager said,

It was a black period in user support because the incomplete software was too difficult to use and it had many mistakes. The partner did not support us because of the project cancellation. Correcting mistakes as well as developing the last 30 percent was an overload for the IT staff.

An IT center (for Bao Viet Life) was established by Baoviet in June 2001 to include personnel from the IT department and personnel from the project group. This helped a more confident continuation of the development and modification of the life insurance software in-house. The Software Development Manager reported,

The establishment of the IT center demonstrated the investment and concern of senior management. It has brought a certain efficiency. We have about 30 IT staff with more servers, better information systems, and especially improved working and development procedures.

They had software development procedures to apply which they did not have before. Thus, the systems were more accurate and robust than before.

When initially installed, the software had so many errors that IT staff had to upgrade it almost every day. It was very frustrating for both business and IT people.

Most of the upgrades (about 60 to 70 percent) stemmed from software mistakes that were written by the local partner. About 30 percent of the upgrades were to meet the business and user requirements.

In a situation of swimming or sinking, the IT staff had to learn and cope with the situation very quickly and very intensely. They strongly believe that they learned while doing their jobs. 


\subsection{Achievements}

In a report on IT development strategy (2003) for the life insurance business, written by the Baoviet IT Center, the main principle was no longer self-sufficiency but it was a move to making use of outsourcing strategy. This was developed at the time that Bao Viet Life was about to become an independent, autonomous business.

The strategic objective of Baoviet information systems for Bao Viet Life was specified as

to meet the insurance and investment business requirements, to support the decision making process and management, to improve service quality and to create competitive advantage in the market for Bao Viet Life.

By 2003, the IT staff had completed the software. The previously incomplete 30 percent was fulfilled. The software now has enough functionality and can satisfy operational requirements from the business departments. Some 45 percent of survey respondents agreed that the information systems now satisfy or fully satisfy the business requirements while another 47 percent said information systems do satisfy business requirements but need to be improved. Due to the decentralized data model and the need to transport and merge each branch's data, sometimes reports did not meet the head office management requirements, nor were they timely. Most respondents ( 85 percent) agreed that, although Bao Viet Life's IT capability still has some weaknesses, it has been progressing in comparison with the past several years.

Bao Viet Life staff have learned while doing their job; they have learned how to manage projects better and gained technical and management skill from the partner. More significantly, they (IT staff) have learned by doing their own modification and correction of software, and they have gained good knowledge of the life insurance business - this was agreed by 87.5 percent of both IT and business people replying to the survey. Most of the interviewees believed that the relationship between business and IT staff has been getting better over time. Most people ( 92.5 percent) believed that Bao Viet Life's senior management has strongly encouraged their staff in using IT applications in their job.

One of the IT management commented,

In the past, we had to upgrade the software almost every day. And after that the frequency was once per 5 days. Now, it is once a week ( 7 days). And in some weeks, there is only some small thing or nothing to upgrade.

Various reasons for the reduced frequency of software upgrades were specified by a senior software staff,

Business staff have been getting a better understanding of life insurance business. Thus their requirements are much more sufficient and understandable now. They are no longer making so many changes in their business procedures....IT staff's technical skills and business skills are much better than before. They have also got more experience in managing and solving 
problems....The relationship between IT and business staffs has been getting better.

In assessing the staff skills and competency, the IT manager said that

For technical problem solving, IT staffs are now really much faster than before thanks to their strong experience, knowledge, and better technology. At present, IT staff are good at Oracle. They are even better than staff of all other IT companies except FPT). ${ }^{2}$

Most of the interviewees agreed that if they could do it all again, they would still choose the same strategy that Baoviet had chosen but they would focus more on management and implementation.

In its SWOT analysis in 2004, one of the main strengths identified in Bao Viet Life's IT Center, was that,

Bao Viet Life IT staff are qualified and active enough to manage, to absorb, and to develop its information technology systems.

The main principle guiding the development of information systems to 2010 was

to make use of outsourcing, combining with the coordination and strictly management and synchronous proceeding in proper phases.

For Bao Viet Life, insurance software, part of the plan for the 2004-2005 period, was to improve the existing software while reevaluating the system design and determining the weaknesses of the systems and how to overcome them, It also needed to prepare for building new software systems in 2005-2006. During 2006-2007, the plan is to redesign the whole system, building web facilities and a Bao Viet Life call center.

In the 2005 final half-year plan, it was specified that the Information Center has to

prepare alternative solutions for replacing BVLIFE- the existing softwarefor the centralization of management direction.

Bao Viet Life has started the implementation of this strategy with several study projects. In October 2005, some vendors were called to present package solutions for the life insurance business. Bao Viet Life has found itself back in the decision situation it faced in 1999, only this time it is far better prepared and senior management are prepared to abandon the solutions so painstakingly developed over the intervening period. Bao Viet Life also faces this decision as an autonomous business unit.

${ }^{2} \mathrm{FPT}$ is currently recognized as the leading IT company in Vietnam. 


\section{DISCUSSION}

The discussion will first analyze the process of building the IT capability of the company, following the main sequences of the special situations in that process. Then, based on the frameworks mentioned earlier, an analysis will be done to see if the company was successful in building its IT capability as a result of improvisation.

\subsection{Improvisation}

The analysis approach of Silva (2002) is used to identify the situations in which key management actions took place. These are summarized in Table 1 . The special/critical situations in the table are the conditions that trigger a decision or action taken which was assessed as improvisation. Bricolage is recognized when "making do" is observed.

In the first situation, insurance was a new business with relatively small revenue and few staff. One staff member in the business area developed simple software by himself, initially for only his use. This kind of situation is seen as improvisation because there was "no split between composition and performance...no split between design and production" (Weick 1993, p. 131, cited in Miner et al. 2001, p. 313). The development of software occurred during normal work.

In the second situation, Baoviet was faced with unanticipated fast growth of its business and its internal problem of lack of software. It decided to develop the software using available personnel and resources in the IT department, making do with what was available. Such development was unanticipated and had not been provided for. Although this decision action contains all of the characteristics of improvisation, it apparently features more bricolage (Cunha et al. 1999).

Table 1. Situation and Action Analysis (based on Silva 2002)

\begin{tabular}{|l|l|l|l|}
\hline Special Situation & $\begin{array}{c}\text { Organizational } \\
\text { Situation }\end{array}$ & \multicolumn{1}{c|}{ Action Taken } & Main Feature \\
\hline $\begin{array}{l}\text { Newly launched } \\
\text { business in a new } \\
\text { emerging market }\end{array}$ & $\begin{array}{l}\text { New and small } \\
\text { insurance business }\end{array}$ & $\begin{array}{l}\text { Software developed } \\
\text { by business staff. }\end{array}$ & $\begin{array}{l}\text { Improvisation and } \\
\text { bricolage }\end{array}$ \\
\hline $\begin{array}{l}\text { Fast growth } \\
\text { business }\end{array}$ & $\begin{array}{l}\text { Software did not } \\
\text { meet business } \\
\text { demand }\end{array}$ & $\begin{array}{l}\text { New comprehensive } \\
\text { software developed } \\
\text { by IT department }\end{array}$ & Bricolage \\
\hline $\begin{array}{l}\text { Information tech- } \\
\text { nology market } \\
\text { growth. } \\
\text { Competition } \\
\text { introduced }\end{array}$ & $\begin{array}{l}\text { Had to cope with } \\
\text { business demand } \\
\text { and competition }\end{array}$ & Local outsourcing & Improvisation \\
\hline $\begin{array}{l}\text { Outsourcing } \\
\text { project failed }\end{array}$ & $\begin{array}{l}\text { Better knowledge } \\
\text { and capable staff. }\end{array}$ & $\begin{array}{l}\text { Continued in house } \\
\text { building the software. }\end{array}$ & $\begin{array}{l}\text { Bricolage } \\
\text { improvisation }\end{array}$ \\
\hline
\end{tabular}


The introduction of competition in the insurance market could be considered as a very critical emergent situation for a monopoly company such as Baoviet. Competition was unexpected and the way it worked was unanticipated. Baoviet did not possess any kind of preplanned course of action and fast action was required. Thus, the local outsourcing decision that took place was again improvisation.

The last situation was also unexpected and had not been planned for. It could be seen as a crisis because it "characterized by low probability/high consequence events that threaten... fundamental goals of an organization" (Weick 1988). Baoviet decided to build its software in-house with all resources available (a bricolage feature). This action also was an improvisation action itself because it "comes into being as a response to a crisis" (Weick 1993, cited in Silva 2002).

Through those four critical situations, which occurred in the process of building IT capability in Baoviet, it could be seen that improvisation has been a pattern of actions. Using the notion of strategy as "a pattern in actions over time" (Mintzberg 1994), we argue that improvisation was indeed the strategy adopted by Baoviet. This strategy is unusual itself, however, an important question is whether it was a success. The Baoviet IT capability will now be analyzed.

\subsection{The Outcomes of Improvisation}

The section will follow the cited frameworks to analyze Bao Viet Life's achievements in building IT capability using the evidence of the interviews and survey. Two earlier stages are used to draw a contrast with the present situation. Stage 1 represents the time (1999) at which Baoviet approached a local software company to develop its life insurance application. Stage 2 (2001) was the point at which the application was then brought in-house. The current state is based on the case study investigation in 2005. Table 2 shows the capability assessment following Feeny and Willcock's model over the three periods.

In all strategy documents and reports from Baoviet senior management and IT leaders, IT goals and directions have consistently been set. These have supported the IT staff's belief that their first priority is to contribute to meeting business demands and achieving business solutions. So, there is/IT leadership competency could be assessed as good over time using either Feeny and Willcock's model or Ward and Peppard's.

In Baoviet, the business development has been integrated with the IT capability reasonably well. Business processes were changed to meet business demands, subject to current IT ability both in staff skills and the technology itself. In the IT manager's opinion, currently IT follows business demands but in the future "technology will lead to business changes."

Due to the "culture gap between techies and users" (Feeny and Willcocks 1998, p. 13), Baoviet IT and business staff had only a basic working relationship in the beginning. They would only talk with each other if needed. Later, IT and business staff had to cooperate strongly together over the intervening period to get their job done. For mutual benefit, they had no choice but to cooperate closely with each other. Thus, their working relationship has been getting closer and better. Now, there is a mutual confidence, shared purpose, and efficient communication. The relationship building competency has improved significantly over time, from fair in the first two periods to be good now. 
Table 2. Baoviet's IT Competencies Using the Feeny and Willcocks Framework

\begin{tabular}{|c|c|c|c|c|c|}
\hline No. & Competency & Explanation & $\begin{array}{c}\text { Stage } \\
1\end{array}$ & \begin{tabular}{|c|} 
Stage \\
2 \\
\end{tabular} & Now \\
\hline 1 & IS/IT leadership & $\begin{array}{l}\text { Integrating IS/IT effort with } \\
\text { business purpose and activity }\end{array}$ & Good & Good & Good \\
\hline 2 & $\begin{array}{l}\text { Business } \\
\text { system thinking }\end{array}$ & $\begin{array}{l}\text { Envisioning the business } \\
\text { processes that technology } \\
\text { makes possible }\end{array}$ & Fair & Good & Good+ \\
\hline 3 & $\begin{array}{l}\text { Relationship } \\
\text { building }\end{array}$ & $\begin{array}{l}\text { Getting the business } \\
\text { constructively engaged in } \\
\text { IS/IT issues }\end{array}$ & Fair & Fair & Good \\
\hline 4 & $\begin{array}{l}\text { Architecture } \\
\text { planning }\end{array}$ & $\begin{array}{l}\text { Creating a coherent blueprint } \\
\text { for a technological platform } \\
\text { that responds to current and } \\
\text { future business }\end{array}$ & $\begin{array}{l}\text { Not } \\
\text { good }\end{array}$ & \begin{tabular}{|l|} 
Not \\
good
\end{tabular} & $\begin{array}{l}\text { Not } \\
\text { good }\end{array}$ \\
\hline 5 & $\begin{array}{l}\text { Making } \\
\text { technology } \\
\text { work }\end{array}$ & $\begin{array}{l}\text { Rapidly achieving technical } \\
\text { progress by one means or } \\
\text { another }\end{array}$ & Average & Fair & Good \\
\hline 6 & $\begin{array}{l}\text { Informed } \\
\text { buying }\end{array}$ & $\begin{array}{l}\text { Managing the IS/IT sourcing } \\
\text { strategy that meets the } \\
\text { interests of the business }\end{array}$ & Fair & Good & Good \\
\hline
\end{tabular}

Stage 1: Local company develops software; Stage 2: Brought in-house

The two critical contributions of Baoviet IT staff that make technology work are that they "rapidly troubleshoot problems that are disowned by others across the technical supply chain" and they identify "how to address business needs that can not be properly satisfied by standard technical approaches" (Feeny and Willcocks 1998, p. 13). Thus, Bao Viet Life has achieved significant improvement in this capability. In its current state, Bao Viet Life has few outsourced services, so the "informed buying" has not been developed as a capability. However, with the experience from the past IT project, Bao Viet Life has improved its capability at managing the IS/IT sourcing strategy and that is upgraded to good.

One of the critical weaknesses recognized by the IT manager and IT staff is the inflexibility of the technological platform. Thus we assess Bao Viet Life's current IT infrastructure as unable to respond to future business requirements. This area is the one that needs to be focused on and improved by senior management and IT leaders.

For outsourcing related competencies (contract facilitation, contract monitoring, vendor development), insufficient evidence was collected to assess those competencies and they have been omitted from the analysis. These capabilities should have improved if Baoviet staff have been learning the experiences from past projects; however, we reserve this area for further study.

The above analysis shows that Baoviet's IT capability has also been improved substantially using the IT capability components draw from Ross et al. (1996) and Peppard and Ward (2004), IT and business knowledge and skills, and the relationship between IT and business people. The only improvement not supported by the evidence collected is in technology infrastructure. 
Table 3. Selected Baoviet IT Abilities Using Ward and Peppard's Framework

\begin{tabular}{|l|l|l|c|c|c|}
\hline & Ability & \multicolumn{1}{|c|}{ Explanation } & $\begin{array}{c}\text { Stage } \\
\mathbf{1}\end{array}$ & $\begin{array}{c}\text { Stage } \\
\mathbf{2}\end{array}$ & Now \\
\hline 1 & $\begin{array}{l}\text { Business } \\
\text { strategy }\end{array}$ & $\begin{array}{l}\text { ability to ensure that business strategy } \\
\text { formulation identifies the most } \\
\text { advantageous uses of IS and IT }\end{array}$ & Good & Good & Good \\
\hline 2 & $\begin{array}{l}\text { Benefits } \\
\text { delivery }\end{array}$ & $\begin{array}{l}\text { ability to monitor, measure and evaluate } \\
\text { the benefits delivered from IS/IT } \\
\text { investment and use }\end{array}$ & Poor & Fair & Good \\
\hline 5 & $\begin{array}{l}\text { Benefits } \\
\text { planning }\end{array}$ & $\begin{array}{l}\text { an ability explicitly to identify and plan to } \\
\text { realize the benefits from IS investments }\end{array}$ & Poor & Fair & Good \\
\hline
\end{tabular}

Stage 1: Local company develops software; Stage 2: Brought in-house

Additional analysis using Ward and Peppard's model (2002) is shown in Table 3. As only three out of eight abilities can be assessed with enough evidence, the remainder are omitted. In terms of business strategy, Baoviet's business strategies show that it is consistently good over time. Evidence from questionnaires, interviews, and the company's written documents demonstrate Baoviet's significant improvement in its benefits delivery and benefits planning abilities. For the other abilities, we were unable to assess any improvement as this required access to senior management, who have not yet participated.

The achievement of Bao Viet Life through its "learning by doing" process could be better understood by using Andreu and Ciborra's (1996) basic learning processes. In other words, the approach to transform from lower levels of capabilities to higher levels in Baoviet is the improvisation process itself. Through the challenging period of coping with the increasingly competitive market combined with its scarce financial and human resources, Baoviet staff have substantially developed their work practices (regularly upgrading IT systems and software and improving their knowledge, skills, and working relationships). Its IT capability has been developed from these work practices. The question of whether IT has become a core capability in Baoviet could not be answered, but this is part of the ongoing research. It is at this point, with the possibility of adopting a world-class software package, that such capability will be revealed. However, we could see that the capability development process has been effective in understanding the situation in Baoviet.

\section{IMPLICATIONS}

Building IT capability in this case actually is a sequence of improvisation actions. Thus, improvisation can be seen as Baoviet's strategy itself. Furthermore, it is a successful improvisation case, which might be a good example from which other companies with the same situation, especially in developing countries, might learn.

Transformation of organization through IT is usually seen as relevant to sophisticated organizations. This paper takes the transformation idea wider to include IT and shows that the IT and the organization can engage in simultaneous transformation. Two models in particular-Andreu and Ciborra (1996) and Feeny and Willcocks (1998) 
have been useful in the analysis. They have been particularly powerful in identifying the areas where development is least or unknown. This indicates that the models could usefully be applied as diagnostic tools or guidance instruments for organizations with limited IT capability.

Senior management took an unusual long-term perspective in deciding to develop capability with an in-house attempt at software development, with the certain understanding that this would be replaced when the organization had the capability to evaluate and to implement systems. They entered into that decision knowing that whatever software was developed would be written off in the near future. They retained the idea of installing best-practice systems, once their staff could understand and work them. The business was expected to make-do or simply do-its-best with the goal of learning. Such improvisation as a strategy is in itself an unexpected finding from a state-owned enterprise in a developing economy.

\section{References}

Andreu, R., and Ciborra, C. "Organizational Learning and Core Capabilities Development: the Role of IT," Journal of Strategic Information Systems (5), 1996, pp. 111-127.

Applegate, L. M. "Managing in an Information Age: Transforming Organizations for the 1990s," in R. Baskerville, S. Smithson, O. Ngwenyama, and J. I. DeGross (eds.), Transforming Organizations with Information Technology, Amsterdam: North Holland, 1994, pp. $15-94$.

Barrett, F. "Coda: Creativity and Improvisation in Jazz and Organizations: Implications for Organizational Learning, Organization Science (9:5), 1998, pp. 605-622.

Bharadwaj, A. "A Resource-Based Perspective on Information Technology and Firm Performance: An Empirical Investigation," MIS Quarterly (24:1), 2000, pp. 169-196.

Bjørn-Andersen, N., and Turner, J. A. "Creating the Twenty-First Century Organization: The Metamorphosis of Oticon," in R. Baskerville, S. Smithson, O. Ngwenyama, and J. I. DeGross (eds.), Transforming Organizations with Information Technology, Amsterdam: North Holland, 1994, pp. 379-394.

Brown, I. S., and Duguid, P. "Organizational Learning and Communities of Practice," Organizational Science (2:1), 1991, pp. 40-57.

Carr, N. "IT Doesn't Matter," Harvard Business Review, May 2003, pp. 41-49.

Ciborra, C. "Notes on Improvisation and Time in Organizations," Accounting Management and Information Technologies (9), 1999, pp. 77-94.

Clemons, E. K., and Row, M. C. "Sustaining IT Advantage: The Role of Structural Differences," MIS Quarterly (15:4), 1991, pp. 487-505.

Cunha, M. P., Cunha, J. V., Kamoche, K. "Organizational Improvisation: What, When, How and Why," International Journal of Management Review (1:3), 1999, pp. 299-341.

Dvorak, R. E., Holen, E., Mark, D., and Meehan, W. F. "Six Principles of High-Performance IT," McKinsey Quarterly (3), 1997, pp. 164-177.

Feeny, D. F., and Ives, B. "In Search of Sustainability," Journal of Management Information Systems (7:1), 1990, pp. 27-46.

Feeny, D. F., and Willcocks, L. P. "Re-Designing the IS Function Around Core Capabilities," Long Range Planning (31), 1998, pp. 354-367.

Hammer, M., and Champy, J. Reengineering the Corporation, New York: HarperCollins, 1993. Kamoche,K., Cunha, M. P., and Cunha, J. V. "Towards a Theory of Organizational Improvisation: Looking Beyond the Jazz Metaphor," Journal of Management Studies (40:8), 2003, pp. 2021-2051. 
Mata, F. J., Fuerst, W. L., and Barney, J. "Information Technology and Sustained Competitive Advantage: A Resource-Based Analysis," MIS Quarterly (19:4), 1995, pp. 487-505.

McFarlan, F. W. "Information Technology Changes the Way You Compete," Harvard Business Review, May-June 1984, pp. 93-103.

Miner, A. S., Bassoff, P., and Moorman, C. "Organizational Improvisation and Learning: A Field Study," Administrative Science Quarterly (46), 2001, pp. 304-337.

Mintzberg, H. The Rise and Fall of Strategic Planning: Reconceiving Roles for Planning, Plans, and Planners, New York: Free Press, 1994.

Moorman, C., and Miner, A. S. "The convergence of planning and execution: improvisation in New Product Development, Journal of Marketing (62:3), 1998a, pp. 1-20.

Moorman, C., Miner, A.S. (1998b), Organizational improvisation and organization memory, Academy of Management Review (23:4), 1998b, pp. 698-723.

Orlikowski, W. J. "Improvising Organizational Transformation Over Time: A Situated Change Perspective," Information Systems Research (7:1), 1996, pp. 63-92.

Orlikowski, W. J., and Hoffman, J. D. "An Improvisational Model for Change Management: The Case of Groupware Technologies," Sloan Management Review, Winter 1997, pp. 11-21.

Peppard, J., and Ward, J. "Beyond Strategic Information Systems: Towards an IS Capability," Journal of Strategic Information Systems (13), 2004, pp. 167-194.

Porter, M., and Millar, V. E. "How Information Gives You Competitive Advantage" Harvard Business Review, July-August 1985, pp. 149-160.

Ross, J., Beath, C. M., and Goodhue, D. L. "Develop Long-Term Competitiveness through IT Assets," Sloan Management Review (38:1), 1996, pp. 31-42.

Silva, L. O. "Outsourcing as Improvisation: A Case Sstudy in Latin America," The Information Society (18), 2002, pp. 129-138.

Turban, E., Leidner, D., McLean, E., and Wetherbe, J. Information Technology for Management: Transforming Organizations in the Digital Economy, New York: Wiley, 2004.

Ward, J., and Peppard, J. Strategic Planning for Information Systems ( $3^{\text {rd }}$ ed.), Chichester, UK: Wiley, 2002.

Weick, K. E. "Enacted Sensemaking in Crisis Situations," Journal of Management Studies (25:4), 1988, pp. 305-317.

Weick, K. E. "Introductory Essay: Improvisation as a Mindset for Organizational Analysis," Organization Science (9:5), 1998, pp. 543-592.

Weick, K.E. "Organizational Redesign as Improvisation," in G. P. Huber and W. H. Glick (eds.), Organizational Change and Redesign: Ideas and Insights for Improving Performance, $\mathrm{New}$ York: Oxford University Press, 1993, pp. 345-379,

\section{About the Authors}

Thi Lien Pham is a scholarship Ph.D. student at Macquarie Graduate School of Management, Macquarie University, Australia. This paper relates to part of her Ph.D. research. She had 5 years working experience as a management consultant and 2 years as a market researcher in Vietnam. She can be contacted by email to lienpt@hotmail.com.

Ernest Jordan is a professor of Management at Macquarie Graduate School of Management where he teaches e-business and IT management. He has published on the issues of IT strategic alignment, IT governance, and IT risk management. Ernest has extensive experience in information system development and management in major organizations overseas and in Australia. His recent research activity is concerned with matching the IT governance approach to the IT risk portfolio. He can be contacted at Ernest.Jordan@mgsm.edu.au. 